\title{
The influence of thyrotropin-releasing hormone (TRH) on growth rate and thyroid activity in broiler chicks
}

\author{
Elżbieta Wir-Konas, R. Ryś and M. Pietras \\ Institute of Animal Production, Department of Nutrition \\ Sarego 2, 31-047 Kraków, Poland
}

(Received 17 April 1992; accepted 14 December 1992)

\begin{abstract}
Twenty-eight-day old broiler chicks were used to determine growth rate and thyroid activity responses to various doses and routes of administration of synthetic thyrotropin-releasing hormone (TRH). In experiment 1, daily intramuscular (im.) injections of $2 \mu \mathrm{g} \mathrm{TRH} /$ chick over 10 or 20 days stimulated the relative body weight gain in cockerels by 5.7 and $10 \%$, respectively, compared with saline injected controls. In experiment $2, \mathrm{TRH}$ administered im. $(2 \mu \mathrm{g} / \mathrm{chick})$ or orally $(80 \mu \mathrm{g} / \mathrm{chick})$ over 10 days significantly increased $(P \leqslant 0.01)$ the relative body weight gain of cockerels by 20.3 and $29.6 \%$, respectively and slightly improved feed conversion efficiency. No effect of TRH on the growth rate of female chicks was found. Treatment with TRH induced a marked inercase of relative thyroid size, basal metabolic rate and plasma triodothyronine and thyroxine levels. Our data confirmed earlier reports that improvement in growth rate of TRH-treated chicks appears to be mediated by thyroid hormones.
\end{abstract}

KEY WORDS: chicks, TRH, growth, thyroid activity

\section{INTRODUCTION}

In all vertebrates, except fish, the hypothalamic tripeptide thyrotropin-releasing hormone (TRH) is known to stimulate the synthesis and release of thyroid hormone i.e. triiodothyronine $\left(\mathrm{T}_{3}\right)$ and thyroxine $\left(\mathrm{T}_{4}\right)$, both indispensable for normal growth and development of young animals. Thus, administration of exogenous TRH may lead to augmented thyroid hormone levels and consequently to accelerated growth rates. In mammals, this growth-promoting effect has been demonstrated with intravenous (iv.) or intramuscular (im.) injections of TRH into cattle (McGuffey et al., 1977; Davis et al., 1977; Muir and Wier, 1987) and lambs (Davis et al., 1976).

The possible anabolic effect of exogenous TRH on birds has been tested in several experiments. The results of studies by Leung et al. (1984) indicated that daily iv. injection of 1 or $10 \mu \mathrm{g} \mathrm{TRH} /$ chick for 17 days increased the growth rate 
of 28 -day old male chickens by about $12 \%$ compared with saline injected controls. Significant non-dose-related increase of plasma $T_{3}$ and $T_{4}$ concentrations were observed. Peak circulating hormone levels appeared $1 \mathrm{~h}$ after TRH injection (Leung et al., 1984; Kahl and Rząsa, 1980; Kühn et al., 1991). On the other hand in the experiment of Buonomo and Baile (1986) daily iv. injection of TRH for 21 days failed to stimulate the growth rate of cockerels, despite enhanced growth hormone $(\mathrm{GH})$ secretion. It was also claimed that TRH injected iv. into adult birds is not thyrotropic but has a somatotropic effect and is responsible for the peripheral conversion of $T_{4}$ into $T_{3}$ (Kühn et al., 1991).

Most authors employed iv., im. or subcutaneous (sc.) routes of TRH administration. Because TRH is a small peptide, Burke and Vaughters (1984) tried to study the effect of its oral administration to chicks in either feed or drinking water. Although exogenous dietary TRH increased secretion of plasma $\mathrm{GH}$, the growth rate of chicks was not affected. In contrast, Cogburn et al. (1989) reported that a large dose of TRH in feed given for 21 days stimulated the growth rate of chickens by $14 \%$ and plasma $\mathrm{T}_{3}$ level by $38 \%$ when compared with a control group.

The present study was designed to determine the effect of thyroid manipulation using synthetic TRH as an intrumuscular or oral active growth stimulant in growing broiler chickens.

MATERIAL AND METHODS

One hundred twenty seven twenty-eight day old nonsexed White Rock $\times$ Cornish broiler chickens were used in two separate experiments. In both experiments chickens were divided at random into 3 groups, each of 21 or 22 birds, and kept on natural lighting schedule in individual cages with free access to standard diet and water. The standard ration contained $19.7 \%$ crude protein and $3100 \mathrm{kcal}$ metabolizable energy $/ \mathrm{kg}$. During the 20 days of experiment the body weight and feed intake were recorded and feed conversion ( $\mathrm{g}$ feed/g gain) calculated.

The purpose of experiment 1 was to determine the effect of daily im. injection with $2 \mu \mathrm{g} \mathrm{TRH} /$ chick for 10 or 20 days on growth rate, basal metabolic rate (BMR), thyroid size and plasma $T_{3}$ level. The birds of control group were injected with $0.5 \mathrm{ml}$ saline solution for 20 days. On day 1, 5, 10, 15 and 20 blood samples were collected into heparinized syringes from the wing veins of 10 chickens of each group $1 \mathrm{~h}$ after TRH or saline injections. After centrifugation the plasma was stored at $-20^{\circ} \mathrm{C}$ until assayed for $\mathrm{T}_{3}$ levels.

The BMR was determined on 10 chicks from each group on days 10 and 20 of the experiment on the basis of $\mathrm{O}_{2}$ and $\mathrm{CO}_{2}$ concentrations in expired air using a universal Type M.G.-4 diaferometer (Kipp and Zonen, Delft, Holland). 
Chickens fasted for $12 \mathrm{~h}$ overnight were placed individually in a temperature-controlled box. Measurements of $\mathrm{O}_{2}$ and $\mathrm{CO}_{2}$ were done between 8.00 and $12.00 \mathrm{~h}$ in a thermoneutral environment. After the adaptation period the $\mathrm{O}_{2}$ consumption of each chick was recorded for 2 consecutive $10 \mathrm{~min}$. readings. The results were extrapolated to a $1 \mathrm{~h}$ period and expressed as $\mathrm{O}_{2} \mathrm{ml} / \mathrm{g}$ body weight. At the end of the experiment the birds were weighed, killed by decapitation and sexed. The thyroid glands were dissected and weighed.

A more practical form of TRH administration was the subject of experiment 2. Ingestion of TRH was assessed in terms of its effect as an active growth and thyroid hormone stimulant in 28-days old male and female broiler chickens. As in the previous experiment, one group of chickens received TRH intramuscularly at a dose of $2 \mu \mathrm{g} /$ chick, the second group received $80 \mu \mathrm{g} /$ chick directly into the crop, control group received im. injection of saline solution for 10 days. During this time and for the following 10 days birds were fed to appetite the standard ration as in experiment 1 . The samples of blood were collected as in experiment 1 and, additionally, on day 3 . Both plasma $T_{3}$ and $T_{4}$ levels were measured. The growth performance data of chickens were determined as in experiment 1 .

The TRH preparation used was synthetized in the Institute of Chemistry, University of Gdańsk. TRH was dissolved in physiological saline and stored at $-10^{\circ} \mathrm{C}$ in sterile ampoules.

Plasma $T_{3}$ and $T_{4}$ levels were measured using radioimmunoassay kits supplied by the Polish Institute of Nuclear Research, Centre of Isotope Production and Distribution.

Unfortunately, in both experiments, the average initial body weight of 28-days old control chickens differed from this of the corresponding TRH-treated groups. In order to minimize this effect the relative body weight gain i.e. gain of 48-days old chickens: intitial body weight (\%) was calculated.

The Duncan test was used for comparison of the means of these data only. The differences between plasma $T_{3}$ and $T_{4}$ levels, BMR and relative thyroid size of treated versus non-treated birds were compared using the Student-t test.

\section{RESULTS}

\section{Experiment 1}

Daily injection of $2 \mu \mathrm{g}$ TRH over 10 or 20 days induced significant increase 5.7 and $10 \%$, respectively, in relative body weight gain of male chickens as compared with control ones (Table 1). Feed efficiency in both, TRH-treated and control groups was similar. TRH injections into female chickens did not alter the relative growth parameters. 
TABLE 1

The effect of intramuscular injection of $2 \mu \mathrm{g} \mathrm{TRH} /$ chick for 10 or 20 days on the growth parameters of male and female broiler chicks

Experiment 1

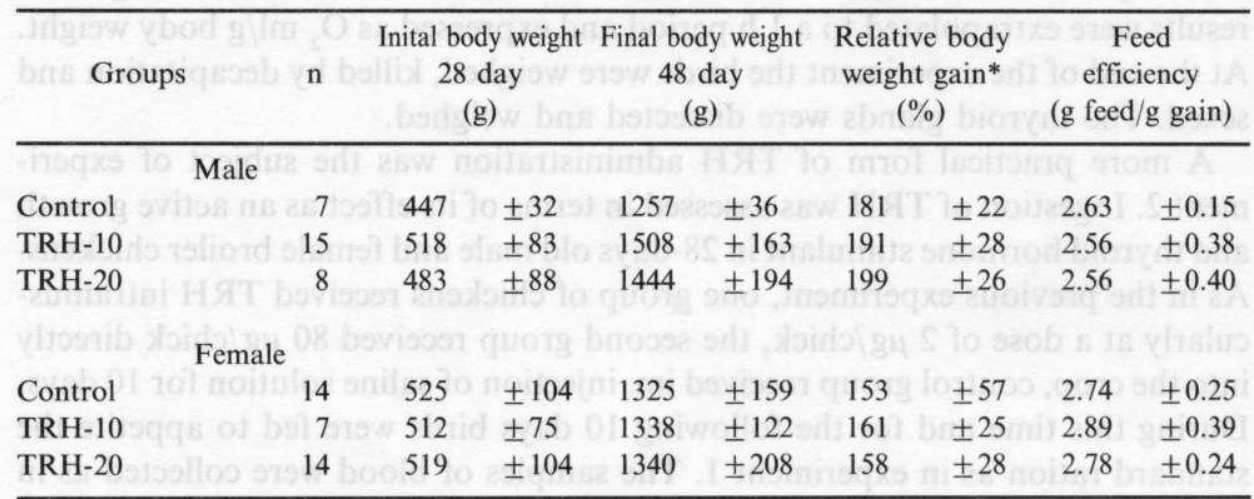

* Relative body weight gain $(\%)=$ (body weight gain: initial body weight $) \times 100$

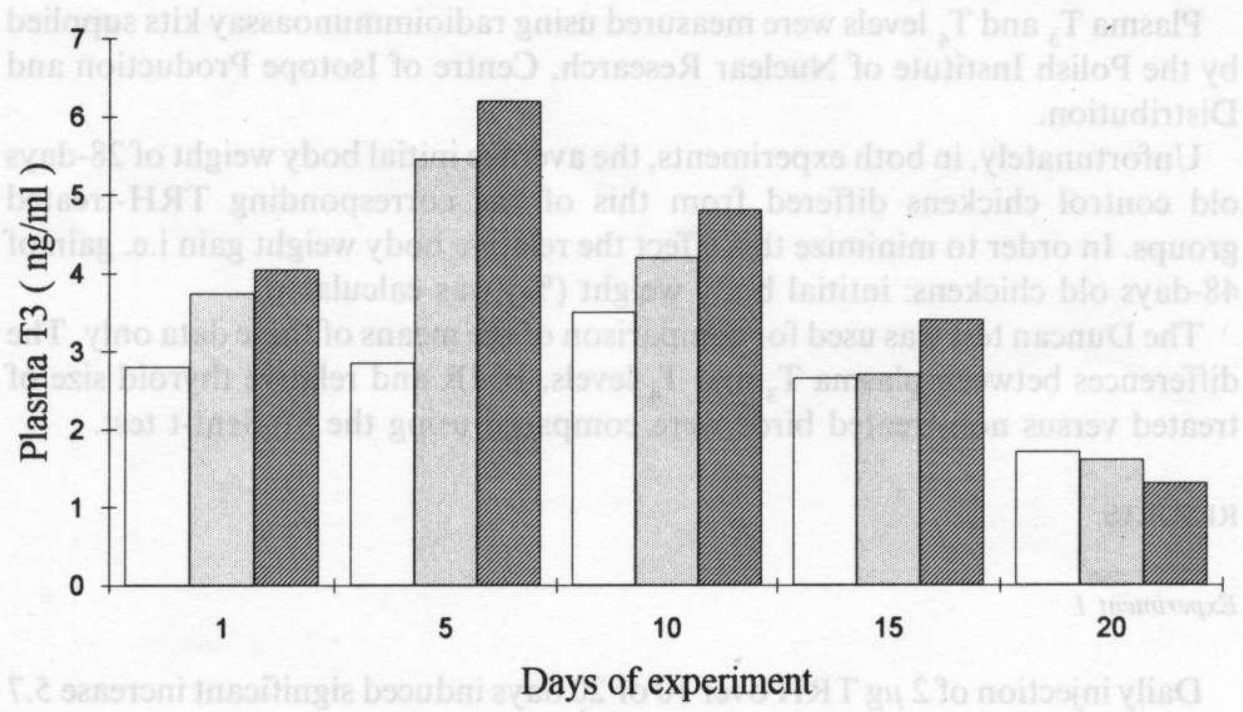

Fig. 1. Expt. 1. Plasma $T_{3}$ levels $\left(\sigma^{\lambda}+q\right.$, Means \pm s.e., $\left.\mathrm{n}=10\right)$ after im. injection of $2 \mu \mathrm{g} T R H$ daily /chick over 10-day ( IIIII), 20-day ( $V / M$ ) , saline control $(\square)$. ${ }^{*} \mathrm{P} \leqslant 0.05 ;{ }^{* *} \mathrm{P} \leqslant 0.01$, statistically different from control group. 


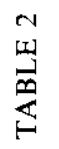

to

$\subseteq$

巳

$\bar{\sigma}$

Z

焉

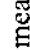

居

気

○

鸢

0

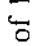

본

$\underline{0}$

政

里

苟

$\bar{g}$

핑

.

$\stackrel{0}{5}$

$\stackrel{\circ}{\frac{\pi}{2}}$

$\frac{0}{0}$

至

离 量翯

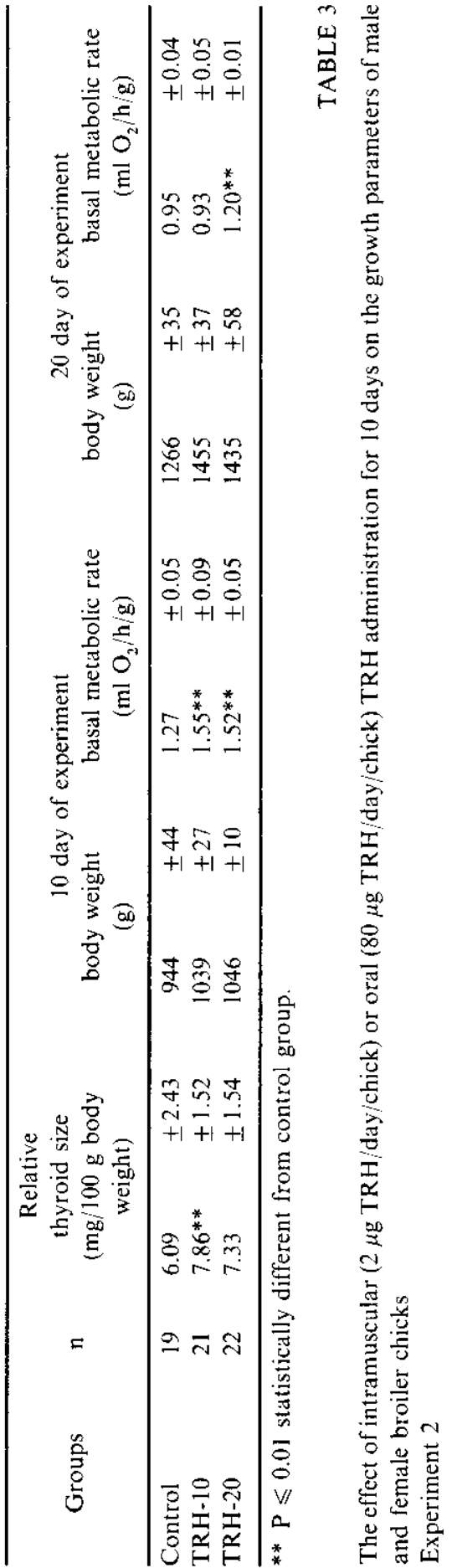

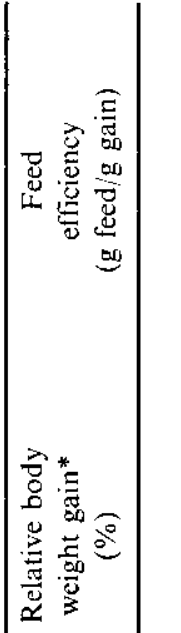

F尺े

$\dot{0} 0 \dot{0}$

$\begin{array}{ccc}2 & m & \infty \\ 0 & 0 & 0 \\ 0 & 0 \\ +1 & +1 & +1\end{array}$

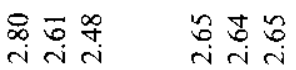

$\underset{+\infty}{+\infty} \frac{m}{+1} \frac{n}{+1}$

$\stackrel{8}{\circ}$

VI

节

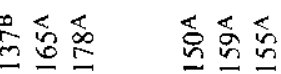

- - $\underline{n}$

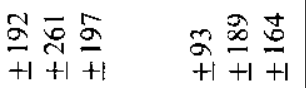

宁

$\frac{1}{20}$

至要

焉

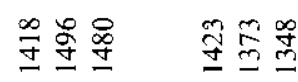

3

吾雚

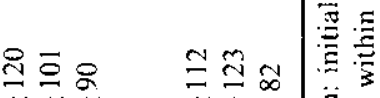

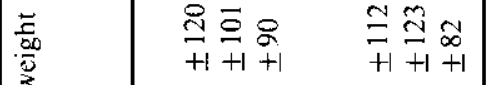

穿

要勇

즐

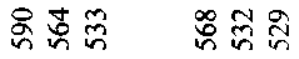

공

3

要

$=$

$\frac{2}{3}$

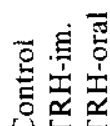

동

亲站 
The effect of im. daily injections of $2 \mu \mathrm{g}$ TRH/chick over 10 or 20 days on plasma $\mathrm{T}_{3}$ level at days 1, 5, 10,15 and 20 is shown in Figure 1. It can be seen that within the first 5 days of TRH injections there was a dramatic elevation in the plasma $T_{3}$ concentration. The mean plasma $T_{3}$ level in group TRH-10 and TRH-20 was higher than in control birds by 30 and $45 \%(\mathrm{P} \leqslant 0.05)$ on day 1 , by 94 and $119 \%(P \leqslant 0.01)$ on day 5 and 21 and $22 \%$ on day 10 , respectively. The plasma $T_{3}$ concentration on day 15 was $35 \%$ higher $(P \leqslant 0.05)$ only in the group receiving prolonged TRH infusion. By day 20 of the experiment, plasma $T_{3}$ level in all birds declined and no differences between groups were noted.

BMR data, expressed as intake of $\mathrm{ml} \mathrm{O}_{2} / \mathrm{h} / \mathrm{g}$ body weight measured after 10 and 20 days of the experiment, demonstrated that $\mathrm{O}_{2}$ consumption increased only during the period of TRH infusion (Table 2). In both experimental groups the $\mathrm{O}_{2}$ intake after 10-days injection period exceeded intake of the control birds by 20 to $22 \%(\mathrm{P} \leqslant 0.01)$. The consumption of $\mathrm{O}_{2}$ on the 20 th day of the experiment was higher by $26 \%(P \leqslant 0.01)$ only in those chickens which received longer TRH treatment. The respiratory quotient $(\mathrm{RQ})$ in fasting chicks for both experimental periods in all of the groups was 0.64 to 0.78 (mean 0.70 \pm 0.012 ).

TRH injections were associated with appreciable thyroid enlargement. In birds treated with TRH over 10 or 20 days the thyroid size increased by 29 and $20.3 \%$, respectively, compared with the control group (Table 2).

\section{Experiment 2}

Data on the effects of oral vs im. TRH administration on growth parameters of male and female chickens are presented in Table 3. TRH treatment over a 10 -day period significantly $(P \leqslant 0.01)$ influenced the relative body weight gain in males but not in females. Relative body weight gain of cockerels which received daily $2 \mu \mathrm{g}$ TRH im. or $80 \mu \mathrm{g}$ TRH orally increased by 20.3 and $29.6 \%$ respectively, in relation to control group. Feed efficiency of cockerels only was improved by 6.8 and $11.4 \%$, respectively.

Both routes of TRH administration resulted in a immediate substantial increase in plasma $T_{3}$ concentration (Fig. 2) at days 1 and 3, but from the day 5 it declined and on consecutive days of the experiment there were no differences among the groups. The plasma $T_{4}$ level rapidly increased within days 1 to 3 of the TRH administration, remained elevated on day 5 and declined to the level of control over the next days of the experiment. Plasma $\mathrm{T}_{4}$ level in im. and orally TRH-treated groups surpassed this of control group by 53 and $10 \%(P \leqslant 0.01)$ on day 1 , by 83 and $75 \%(P \leqslant 0.01)$ on day 3 and by 65 and $26 \%(P \leqslant 0.01)$ on day 5 , respectively. The changes in plasma $\mathrm{T}_{3}$ and $\mathrm{T}_{4}$ levels were generally more pronounced in chickens injected with TRH. 

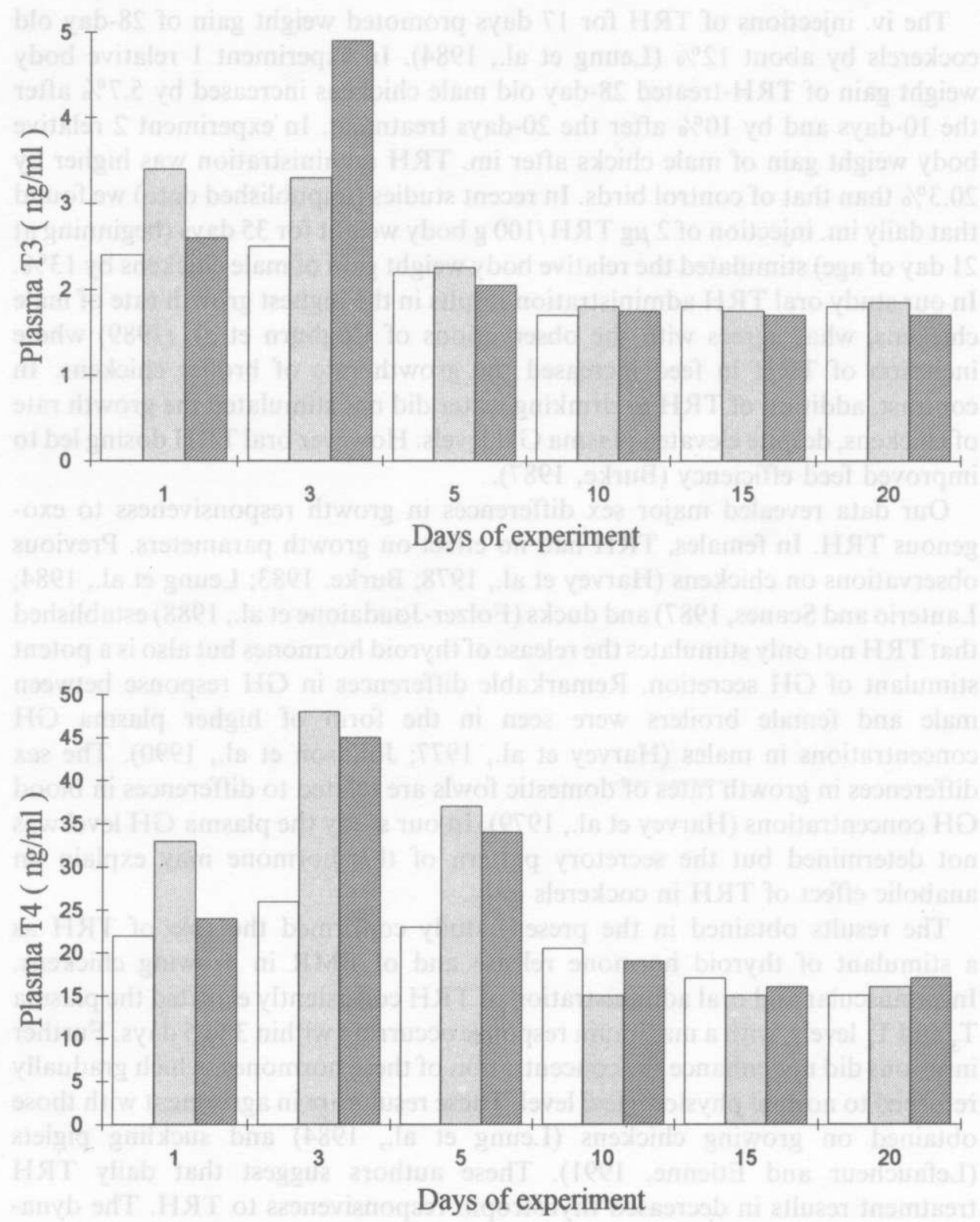

Fig. 2. Expt. 2. Plasma $\mathrm{T}_{3}$ levels $(\delta+q$, Means \pm s.e., $\mathrm{n}=10)$ after im. injection of $2 \mu \mathrm{g}$ TRH daily /chick ( $|I|||)$ ), oral administration of $80 \mu \mathrm{g}$ TRH daily/chick ( $\mathrm{P} \leqslant 0.01$, statistically different from control group. 


\section{DISCUSSION}

The iv. injections of TRH for 17 days promoted weight gain of 28-day old cockerels by about $12 \%$ (Leung et al., 1984). In experiment 1 relative body weight gain of TRH-treated 28-day old male chickens increased by $5.7 \%$ after the 10-days and by $10 \%$ after the 20 -days treatment. In experiment 2 relative body weight gain of male chicks after im. TRH administration was higher by $20.3 \%$ than that of control birds. In recent studies (unpublished data) we found that daily im. injection of $2 \mu \mathrm{g} \mathrm{TRH} / 100 \mathrm{~g}$ body weight for 35 days (beginning at 21 day of age) stimulated the relative body weight gain of male chickens by $13 \%$. In our study oral TRH administration results in the highest growth rate of male chickens, what agrees with the observations of Cogburn et al. (1989) where inclusion of TRH in feed increased the growth rate of broiler chickens. In contrast, addition of TRH to drinking water did not stimulated the growth rate of chickens, despite elevated plasma GH levels. However oral TRH dosing led to improved feed efficiency (Burke, 1987).

Our data revealed major sex differences in growth responsiveness to exogenous TRH. In females, TRH had no effect on growth parameters. Previous observations on chickens (Harvey et al., 1978; Burke, 1983; Leung et al., 1984; Lauterio and Scanes, 1987) and ducks (Folzer-Joudaione et al., 1988) established that TRH not only stimulates the release of thyroid hormones but also is a potent stimulant of GH secretion. Remarkable differences in GH response between male and female broilers were seen in the form of higher plasma $\mathrm{GH}$ concentrations in males (Harvey et al., 1977; Johnson et al., 1990). The sex differences in growth rates of domestic fowls are related to differences in blood GH concentrations (Harvey et a1., 1979). In our study the plasma GH level was not determined but the secretory pattern of this hormone may explain an anabolic effect of TRH in cockerels only.

The results obtained in the present study confirmed the role of TRH as a stimulant of thyroid hormone release and of BMR in growing chickens. Intramuscular and oral administration of TRH consistently elevated the plasma $\mathrm{T}_{3}$ and $\mathrm{T}_{4}$ levels, with a maximum response occurring within 3 to 5 days. Further infusions did not enhance the concentration of these hormones, which gradually returned to normal physiological level. These results are in agreement with those obtained on growing chickens (Leung et al., 1984) and suckling piglets (Lefaucheur and Etienne, 1991). These authors suggest that daily TRH treatment results in decreased thyrotropin responsiveness to TRH. The dynamics of the $T_{3}$ response to TRH was similar in both experiments but were higher and longer lasting in experiment 1 in comparison with experiment 2.

The relationship between thyroid activity and BMR in chickens is well known and probably $T_{3}$ is the main metabolically active thyroid hormone in chicks 
affecting the oxygen consumption (Bobek et al., 1977; Leung et al., 1985). Our study indicates that im. TRH treatment of chickens significantly increased BMR and thyroid size. The activation of the thyroid gland i.e. rises in $\mathrm{O}_{2}$ consumption and plasma $T_{3}$ levels were associated with the time-course of TRH administration.

The both routes of TRH administration resulted in more pronounced increases of plasma $T_{4}$ than $T_{3}$ levels. It shows the predominance of the anabolic metabolism induced by the TRH experimental dose. Similarly, a more pronounced response of $T_{4}$ in comparison to $T_{3}$ levels was observed in TRH-treated suckling piglets (Lefaucheur and Etienne, 1991). On the other hand, the hyperthyroidism induced by high dietary TRH intake by growing chickens (Cogburn et al., 1989) or single high iv. dose into adult birds (Kühn et al., 1991) elevated only the plasma $T_{3}$ concentration but not that of $T_{4}$. These authors supposed that the hyperthyroid state induced by high TRH doses increase peripheral conversion of $T_{4}$ into $T_{3}$.

It may be concluded that both im. and oral TRH treatment effectively increase thyroid hormones concentrations in blood of growing broiler chicken but may improve the growth rate of male chickens only.

\section{REFERENCES}

Bobek S., Jastrzębski M., Pietras M., 1977. Age-related changes in oxygen consumption and plasma thyroid hormone concentration in the young chicken. Gen. Comp. Endocrinol. 31, 169-174

Buonomo F.C.. Bailc C.A., 1986. Fffect of daily injections of growth-hormone releasing factor and thyrotropin-relcasing hormone on growth and endocrine parameters in chickens. Dom. Anim. Endocrinol. 3, 269-276

Burke W.H., 1983. Effect of thyrotropin releasing hormone on plasma growth hormone, prolactin and thyroxinc levels and growth of broiler chicks. Poultry Sci. 62, 1394 ( $\Lambda$ bstr.)

Burke W.H., Vaughters P.D., 1984. Growth hormone release in chickens after oral administration of thyrotropin releasing hormone. Poultry Sci. 63, 2278-2284

Burke W.H., 1987. Influence of orally administered thyrotropin releasing hormone on plasma growth hormone, thyroid hormones, growth, feed efficiency, and organ weights of broiler chickens. Poultry Sci. 66, 147-153

Cogburn L.A., Liou S.S., Alfonso C.P., McGuinness M.C., McMurtry J.P., 1989. Dietary thyrotropin-releasing hormone stimulates growth rate and increases the insulin: glucagon molar ratio of broiler chickens. Proc. Soc. Exp. Biol. Med. 192, 127-134

Davis S.L., Hill K.M., Ohlson D.L., Jacobs J.A., 1976. Influence of chronic thyrotropin-releasing hormone injections on secretion of prolactin, thyrotropin and growth hormonc and on growth rate in wether lambs. J. Anim. Sci. 42, $1244-1250$

Davis S.L., Sasser R.G., Thacker D.L., Ross R.H., 1977. Growth rate and secretion of pituitary hormones in relation to age and chronic treatment with thyrotropin-releasing hormone in prepubertal dairy heifers. Endocrinology 100, 1394-1402

Folzer-Joudaione C., Harvey S., Mialke P., 1988. In vitro control of growth hormone secretion by synthetic releasing factors in young and adult ducks. J. Endocrinol. 119, 421-429

Harvey S., Scanes C.G., Falconer J., Bolton N.J., Chadwick A., 1977. Variations in levels of growth hormone, prolactin and somatomedin in the circulation during growth in the domestic fowl. $J$. Endocrinol. 23, $11 \mathrm{P}$

Harvey S., Scanes C.G., Chadwick A., Bolton N.J., 1978. The effect of thyrotropin-releasing 
hormone (TRH) and somatostatin (GH-RIH) on growth hormone and prolactin secretion in vitro and in vivo in the domestic fowl. Neuroendocrinol. 26, 249-260

Harvey S., Scanes C.G., Chadwick A., Bolton N.J., 1979. Growth hormone and prolactin secretion in growing domestic fowl: influence of sex and breed. Br. Poultry Sci. 20, 9- I7

Johnson R.J., McMurtry J.P., Ballard F.J., 1990. Ontogeny and secretory patterns of plasma insulin-like growth factor-I concentrations in meat-type chickens. J. Endocrinol. 124, $81-87$

Kahl S., Rząsa J., 1980. The effect of estradiol and testosterone on thyrotropin-releasing hormone (TRH) induced changes in plasma thyroid hormone concentration in immature chickens. Adv. Physiol. Sci. 88, 253-261

Kühn E.R., Herremans M., Dewil E., Vanderpooten A., Rudas P., Bartha T., Verheyen A., Berghman L., Decuypere E., 1991. Thyrotropin-relcasing hormone (TRH) is not thyrotropic but somatotropic in domestic fowl. Reprod. Nutr. Dévelop. 31, 431-439

Lauterio T.J., Scanes C.G., 1987. The role of thyroid hormones in growth hormone response to protein restriction in the domestic fowl (gallus domesticus). J. Endocrinol. 117, 223-228

Lefaucheur L., Etienne M., 1991. Effect of exogenous thyrotropin-releasing hormone (TRH) administration on plasma levels of triiodothyronine $\left(T_{3}\right)$, thyroxine $\left(T_{4}\right)$ and growth hormone $(\mathrm{GH})$ in chronically catheterized suckling piglets. Dom. Anim. Endocrinol. 8, 601-609

Leung F.C., Taylor J.E., Iderstine van A., 1984. Thyrotropin-releasing hormone stimulates body weight gain and increases thyroid hormones and growth hormone in plasma of cockerels. Endocrinology, 115, 736-740

Leung F.C., Taylor J.E., Iderstine van A., 1985. Effect of dietary thyroid hormones on growth. plasma $T_{3}, T_{4}$ and growth hormone in normal and hypothyroid chickens. Gen. Comp. Endocrinol. 59, $91-99$

McGuffey R.K., Thomas J.W., Convey E.M., 1977. Growth, serum growth hormone, thyroxine, prolactin and insulin in calves after thyrotropin releasing hormone or 3-methyl-thyrotropin releasing hormone. J. Anim. Sci. 44, 422-430

Muir L.A., Wier S., 1987. Effects of thyrotropin-releasing hormone and a thyrotropin releasing hormone analog on growth and selected plasma hormones in lambs. J. Anim. Sci. 57, 139-145

\section{STRESZCZENIE}

\section{Wplyw hormonu wyzwalającego tyreotropinę (TRH) na tempo wzrostu i aktywność tarczycy u kurcząt brojlerów}

Badano wpływ zróżnicowanych dawek i metod podawania syntetycznego hormonu wyzwalającego tyreotropinę (TRH) na tempo wzrostu i aktywność tarczycy u 28-dniowych kurcząt brojlerów. W doświadczeniu l wykazano, że domięśniowe wstrzykiwanie po $2 \mu \mathrm{g}$ TRH dziennie przez 10 lub 20 dni zwiększylo względne przyrosty masy ciała kogutków odpowiednio o 5,7 i $10 \% \mathrm{w}$ porównaniu z kogutkami z grupy kontrolnej, otrzymujących injekcję soli fizjologicznej. Wyniki doświadczenia 2 wskazują natomiast, że wstrzykiwanic po $2 \mu \mathrm{g}$ TRH domięśniowo lub wprowadzenie $80 \mu \mathrm{g}$ TRH do wola przez. $10 \mathrm{dni}$ zwiększylo $(\mathrm{P} \leqslant 0.01)$ względne przyrosty masy ciala kogutków odpowiednio o 20,3 i $29,6 \%$. U kogutów obserwowano przy tym niewielką poprawę efektywności wykorzystania paszy. W obydwóch doświadczeniach nic wykazano wpływu TRH na wyniki luczu kurek. Podawanie TRH zwiększyło względną masę tarczyc, tempo podstawowej przemiany materii oraz poziom trójjodotyroniny i tyroksyny $w$ osoczu krwi. Przeprowadzone badania potwierdrily wcześniejsze doniesienia, że poprawa tempa wzrostu kurcząt może siç odbywać za pośrcdnictwem hormonów tarczycy po podaniu TRH. 